\title{
$\frac{100}{\mathrm{WiT}}$ RPES
}

\section{CZASOPISMA NAUK SPOLECZNYCH: REFLEKSJE W KONTEKŚCIE JUBILEUSZU „RUCHU PRAWNICZEGO, EKONOMICZNEGO I SOCJOLOGICZNEGO”}

Redakcja „Ruchu Prawniczego, Ekonomicznego i Socjologicznego” z okazji stulecia kwartalnika zaprosiła redaktorów, wydawców i autorów związanych z czasopismami nauk społecznych do zabrania głosu na temat kondycji naszych periodyków w początkach trzeciej dekady XXI w. i uwarunkowań wyznaczonych przez dzisiejsze realia.

Jakie są dzisiejsze realia, każdy widzi. Nie sądzę, by warto było wracać do dyskusji i sporów ostatnich 2-4 lat, gdy wypracowywano nową ustawę o nauce i kolejne wersje „wyceny” publikacji, czasopism i wydawnictw. Rozważaliśmy i spieraliśmy się o wiele spraw: o (inter)dyscyplinarność, anglojęzyczność i sprzężenie z zachodnimi domami wydawniczymi, o kryteria punktowania publikacji i rangę wydawnictw, o źródła finansowania i rolę wielkich polskich wydawców (PAN i wiodących uczelni), o specyfikę humanistyki, światowe repozytoria tekstów i indeksowanie, open access i o wiele innych kwestii. Zabieraliśmy głos na różnych forach, formułując sprzeciw naszych reprezentatywnych gremiów, jak również podejmując merytoryczną krytykę przyjętych rozwiązań. Przykładowo, w „Studiach Socjologicznych” (3/2020) odnieśliśmy się do niektórych z tych kwestii w artykułach Kazimierza M. Słomczyńskiego (Co to sa 'nauki socjologiczne' w polskiej klasyfikacji dziedzin i dyscyplin naukowych) i Konrada Kulikowskiegio i Emila Antipowa (Niezamierzone konsekwencje punktozy jako wartości kulturowej polskiej społeczności akademickiej).

W trakcie tych dyskusji i polemik ujawniły się różnorodne stanowiska, niekiedy skutkujace petycjami i protestami. Niektóre z naszych postulatów

\footnotetext{
* Jacek Wasilewski, Instytut Studiów Politycznych PAN, Warszawa, jwasilew@swps.edu.pl, https://orcid.org/0000-0002-9900-1809,

Redaktor naczelny czasopisma „Studia Socjologiczne”.
} 
zostały wzięte przez decydentów pod uwagę, inne pominięto ${ }^{1}$. Teraz nie warto już wracać do przeszłości, a zwłaszcza nie warto rozdzierać szat i lamentować. Należy sobie powiedzieć: jest jak jest i patrzmy na to, co możemy i co powinniśmy zrobić w aktualnych warunkach.

Większość ugruntowanych polskich czasopism nauk społecznych ma za sobą burzliwą i krętą historię. „Ruch Prawniczy, Ekonomiczny i Socjologiczny” jest tego najlepszym przykładem, gdy na 20 lat zamknięto mu usta. Rozmaite koleje losu przeżywał „Przegląd Socjologiczny”. Periodyki powojenne, w tym „Kultura i Społeczeństwo”, „Studia Socjologiczne” i inne, także doświadczały rozmaitych zawirowań (por. np. artykuł Włodzimierza Wincławskiego o okolicznościach powstania „Studiów Socjologicznych” w nr 1/2011). Historia uczy nas - i prowadzi do oczywistego wniosku - że zmieniały się granice, ustroje i rządy, a polskie czasopisma nauk społecznych trwały i działały. Przetrzymywały nieporównanie większe kłopoty, niż są dzisiaj naszym udziałem.

Pomyślałem, że inspiracji i porównań do refleksji nad dzisiejszym stanem periodyków nauk społecznych poszukam w bogatej przeszłości Dostojnego Stulatka, „Ruchu Prawniczego, Ekonomicznego i Socjologicznego”. Czego możemy się od naszych poprzedników nauczyć? Jak oni radzili sobie z wyzwaniami? Czy warto skopiować niektóre ich pomysły? Co wiele dekad temu robiono lepiej, niż my robimy dzisiaj? Ale także: czego winniśmy unikać? Co różni przedwojenny akademicki kwartalnik nauk społecznych od współczesnego? Do kogo adresowali swoje treści oni, a do kogo adresujemy je my? Kto zapełniał ich łamy, a kto zapełnia nasze łamy?

$$
* * *
$$

Zupełnie arbitralnie wybrałem rocznik dwunasty RPEiS z 1932 r., dostępny w repozytorium UAM$^{2}$. Jedyna rzecz, która o tym wyborze zadecydowała, to myśl, że na skali wieku czasopism naukowych dwunastolatek to wczesny dorosły: młody, energiczny, otwarty na świat, lecz już doświadczony i ustabilizowany. Padło na rok 1932, ale równie dobrze mógł być poprzedni czy następny. Nie sięgnąłem do początkowych roczników, rozumiejąc, że dzieciństwo ma swoje prawa i niekoniecznie z podziwianego malucha wyrośnie dojrzały młodzieniec. Nie sięgnąłem także do najnowszych numerów, gdyż to nieuchronnie wiodłoby do porównań między dzisiejszym RPEiS a jego dziewięćdziesięcioletnim dziadkiem, a tego chciałem uniknacc, gdyż nie o ewolucję jednego kwartalnika tu chodzi, lecz o ogólniejsze spojrzenie na czasopisma nauk społecznych.

Dwunasty rocznik RPEiS składa się z czterech numerów, oprawionych (i ujętych w repozytorium) w półroczniki: z. 1 i 2 oraz 3 i 4. Podtytuł głosi: „Organ Wydziału Prawno-Ekonomicznego Uniwersytetu i Wyższej Szkoły Handlowej w Poznaniu”. I poniżej: „Poświęcony nauce i życiu prawnemu

\footnotetext{
${ }^{1}$ Przydatne informacje o procedurze tworzenia wykazu czasopism autorstwa czterech członków Komisji Ewaluacji Nauki zawarte są w „Forum Akademickim” nr 11/2019 (Jak powstał nowy wykaz czasopism naukowych).

$2<$ https://repozytorium.amu.edu.pl/handle/10593/26>
} 
i gospodarczemu ${ }^{3}$ Rzeczypospolitej Polskiej”. Redaktorem naczelnym i kierownikiem działu prawniczego jest Antoni Peretiatkowicz, kierownikiem działu ekonomicznego - Stanisław Rosiński, a kierownikami działu socjologicznego sa Jan Stanisław Bystroń, Czesław Znamierowski i Tadeusz Szczurkiewicz. Objętość całego rocznika to nieco ponad 1100 stron, czyli średnio każdy numer liczy około 275 stron. Nie odbiega to od standardowej objętości wielu współczesnych kwartalników.

Skład dwunastego rocznika RPEiS jest rozbudowany i obejmuje sześć części (działów), oznaczonych cyframi rzymskimi: I. Artykuły; II. Przegląd piśmiennictwa (podzielony na dział prawniczy, ekonomiczny, samorządowy i socjologiczny); III. Przegląd prawodawstwa; IV. Sądownictwo; V. Kronika; VI. Miscellanea.

Już pierwszy rzut oka na zawartość dwunastego rocznika RPEiS ujawnia różnice w stosunku do większości współczesnych czasopism nauk społecznych. Przyjrzyjmy się bliżej całej jego zawartości i poszczególnym częściom składowym. Celem nie jest szczegółowa analiza rocznika i w żadnym wypadku nie jest recenzowanie struktury czasopisma i tekstów sprzed blisko 90 lat, lecz poszukiwanie wskazówek i identyfikacja problemów, które mogą pomóc nam - dzisiejszym redaktorom i wydawcom - w ulepszeniu naszych periodyków. Siłą rzeczy, punktem odniesienia będą dla mnie najlepiej mi znane „Studia Socjologiczne", lecz sądzę, że zbliżone byłoby spojrzenie innych redaktorów kwartalników nauk społecznych.

$$
* * *
$$

Otwierajacy RPEiS 1932 dział I: Artykuły jest zdumiewająco szczupły, zarówno pod względem ilości tekstów, jak ich objętości. W całym roczniku mamy zaledwie 18 artykułów w tej sekcji i zajmuja one z reguły co najwyżej 1/4 objętości każdego numeru. Dla redaktorów przedwojennego RPEiS pojęcie „artykuły” jest najwyraźniej różne od tego, co dzisiaj uważamy za „artykuł naukowy". Sa tam liczne teksty omawiajace i interpretujące akty prawne. Przykładem Odpowiedzialność karna prezydenta Rzeczpospolitej (9 stron), Zasady polskiego kodeksu karnego (11 stron), czy interwencyjny artykuł Konstytucja Rzeszy a prawa mniejszości (5 stron). Mamy omówienia bieżącej sytuacji społeczno-gospodarczej, np. Ludność Polski w 1931 roku (8 stron; wstępne wyniki spisu powszechnego z 1931 r.; pozazdrościć tempa publikacji danych), czy Bank Polski a wspótczesna sytuacja walutowa (11 stron). Mamy też, ale raczej wyjątkowo, teksty teoretyczne, jak np. Kryzys światowy kryzysem teorii Say'a? (9 stron), nawiązujący do opublikowanego rok wcześniej teoretycznego artykułu o przyczynach kryzysu światowego. Jest również obszerna laurka dla „Instytutu prawa międzynarodowego” (16 stron), dzisiaj trudna do wyobrażenia, być może poza krótką wzmianka, oraz czterostronicowy zapis odczytu Floriana Znanieckiego Kultura amerykanska, wygłoszonego w 1931 r.

${ }^{3} \mathrm{~W}$ podtytule nie ma odwołania do życia społecznego, gdyż przez pierwsze lata tytuł kwartalnika to „Ruch Prawniczy i Ekonomiczny”. Zmiana nazwy, poprzez dodanie „i Socjologiczny” nastapiła w roczniku piątym (1925). 
Patrząc z dzisiejszej perspektywy, większość z tych tekstów nie zostałby zakwalifikowany jako ,,artykuł naukowy”, przynajmniej nie w „Studiach Socjologicznych”. Istotna i oczywistą w świetle powyższej charakterystyki różnica jest także fakt, że artykuły w RPEiS z 1932 r. nader rzadko przywołują/ cytuja literaturę: do wyjątków należą teksty, w których są liczniejsze odwołania do publikacji naukowych. Do tych kwestii wrócę w dalszej partii tekstu.

Najbardziej rozbudowana - ku mojemu zaskoczeniu - jest część II: Przegląd piśmiennictwa. Stanowi ona co najmniej połowę objętości każdego numeru. Można w niej wyróżnić (w każdym ze wspomnianych wyżej działów) ${ }^{4}$, cztery typy tekstów. Dwa pierwsze znamy ze współczesnych czasopism. Są to „klasyczne” recenzje, w większości - patrząc z dzisiejszej perspektywy - krótkie (1-2 strony), choć wyjątkowo zdarzają się także cztero-, pięciostronicowe. Nadto notki bibliograficzne, gdzie w kilku-kilkunastu zdaniach informowano czytelników o tematyce/ zawartości danej pozycji literatury. Łącznie recenzji i notek w całym roczniku dwunastym RPEiS naliczyłem 207 (przynajmniej tyle wyszczególnionych jest w spisie treści). Liczba imponująca. Dwa kolejne typy tekstów w Przeglądzie piśmiennictwa sa już raczej niespotykane w dzisiejszych czasopismach.

W RPEiS 1932 zamieszczane sa spisy bibliograficzne rozmaitych publikacji, głównie akademickich, ale także - nazwijmy to - „okołoakademickich”: publicystyki historycznej i politycznej, prawniczych omówień i wykładni, społeczno-gospodarczych analiz i rozpraw etnograficzno-kulturowych. Spisy te sa niezwykle obszerne, w całym roczniku z pewnością wymienionych jest ponad tysiąc pozycji z całego świata ${ }^{5}$. Są to wyłącznie publikacje obcojęzyczne (w każdym razie na polskojęzyczne nie trafiłem) i najnowsze: daty wydania to rok 1931, a niemało jest także z roku 1932.

Czwarty typ informacji, jaki otrzymuje czytelnik Przeglądu piśmiennictwa, to wybór danych o artykułach zamieszczonych w rozmaitych periodykach, raczej nie akademickich, lecz branżowych, ekonomicznych, kulturalno-społecznych, aż po tygodniki. Nie zdołałem dociec, na podstawie jakich kryteriów ten wybór jest dokonywany. Zapewne jest mniej lub bardziej przypadkowy; być może sami autorzy artykułów w czasopismach, wiedząc, że RPEiS odnotowuje takie publikacje, wysyłali do redakcji informacje o swoich tekstach. Tak czy owak, lista artykułów jest zadziwiająco długa i różnorodna. Aby nie być gołosłownym: w poddziale „Polityka agrarna, rolnictwo, leśnictwo, rybołówstwo,

${ }^{4}$ Dodajmy, że cztery główne działy, czyli prawniczy, ekonomiczny, samorządowy i socjologiczny, podzielone są na poddziały, by ułatwić czytelnikowi nawigowanie po „Przeglądzie piśmiennictwa” i odsyłać od razu do tej subdziedziny, która najbardziej go interesuje. Przykładowo, dział socjologiczny podzielony jest na siedem poddziałów: 1 . Wydawnictwa zbiorowe, podręczniki i systemy. Historja socjologji i krytyka. 2. Metodologia. Zagadnienia graniczne i ogólne. 3. Podłoże biologiczne. Warunki zewnętrzne. 4. Życie społeczne. 5. Grupy i typy. 6. Wytwory społeczne 7. Varia. Tu i dalej przywołania i cytaty z dwunastego rocznika RPEiS podawane sa w pisowni oryginalnej.

${ }^{5}$ Przykładowo, bibliografia zamieszczona w drugim półroczu 1932 (zeszyty 3 i 4) na końcu socjologicznego poddziału Życie społeczne - trzeba przyznać, wyjątkowo obszerna - zajmuje 10 stron i zawiera (policzyłem!) 178 pozycji. Ciekawostką jest, że przy niektórych książkach podana jest cena. Mógłbym sobie wówczas np. kupić Kautskiego o rewolucji proletariackiej za 5 marek, a francuskie wydanie książi Władysława Sikorskiego o problemach pokoju za 30 franków. 
myślistwo” działu ekonomicznego w pierwszym półroczu 1932 mamy wskazanych kilkadziesiąt tekstów z czasopism: „Rolnik Ekonomista”, „Inżynieria Rolna”, „Gazeta Rolnicza”, „Tygodnik Rolniczy”, „Polska Gospodarcza”, „Rolnictwo” czy „Poradnik Spółdzielni”. W dziale samorządowym (drugie półrocze 1932) znajdujemy informacje o artykułach opublikowanych między innymi w: „Gaz i Woda”, „Głos Gminy Wiejskiej”, „Pracownik Samorządowy”, „Kronika Warszawy”, „Samorząd”, „Samorząd Miejski”, „Wiedza i Życie” i kilku innych. Te przykłady unaoczniaja, jak szeroki był krag zainteresowań redaktorów (i korespondentów) z jednej, a czytelników z drugiej strony.

Część III. Przegląd prawodawstwa to w pierwszym półroczu 1932 krótki (raptem dwie strony) wykaz nazw i numerów ustaw przyjętych w ostatnich miesiącach poprzedniego roku, opublikowanych w Dzienniku Ustaw. Zdecydowanie bardziej jest to rozbudowane w drugim półroczu 1932. Tutaj mamy bardzo obszerny (blisko stustronicowy) przegląd aktów prawnych, niekiedy obejmujacych dwulecie 1930-1931 (prawo administracyjne), innym razem krótszy okres (np. pierwsze miesiące 1932 r. w przypadku prawa skarbowego), lecz każdorazowo opatrzone komentarzem, omówieniem, a niekiedy także interpretacją i dodatkowymi analizami. Bez wątpienia cenny materiał dla praktykujących prawo.

Część IV. Sądownictwo to przegląd treści aktów prawnych i orzecznictwa rozmaitych sądów, wyjaśnianego (interpretowanego) przez autorytety prawnicze, z reguły sędziów Sądu Najwyższego. Kolejny cenny (i obszerny: w drugim półroczu ponad 60 stron) materiał dla prawników. Zakres omawianych przepisów i wyjaśnień związanych z konkretnymi sprawami jest bardzo szeroki. Dotyczy błahych przypadków (np. wyjaśnienie, że przepis o niedozwolonym pędzeniu spirytusu zachowuje ważność także wówczas, gdy uzyskany trunek ma moc poniżej 85\%), istotnych spraw pracowniczych (np.: „pracodawca nie może żądać od pracownika umysłowego wykorzystanie służącego mu urlopu w okresie trzymiesięcznego wypowiedzenia"), jak i kwestii najwyższej wagi (np. szpiegostwa). Znaczący fragment działu IV zajmują wyjaśnienia/ interpretacje dotyczące tego, jak orzecznictwo z czasu zaborów (rosyjskie, austriackie, pruskie) należy interpretować w świetle nowego polskiego prawa. Pokazuje to, jak głęboko dziedzictwo czasów niewoli wpisane było w tkankę II Rzeczpospolitej.

Dział V. Kronika to w znacznej części analizy ekonomiczne, dokumentujace twardymi danymi załamanie polskiej gospodarki po kryzysie światowym 1929-1930. Jest tu jednak także miejsce - przykładowo - na dyskusję nad kwestia społeczna, a konkretnie nad projektem ustawy o zwalczaniu nierządu. Autor komentarza (adwokat) aprobatywnie odnosi się do proponowanej ustawy, stwierdzajac, że projekt „traktuje jednakowo prostytucję męską i żeńska, zezwalając na nią zasadniczo, a zakazując bezwzględnie jedynie oddawania się nierządowi z i przez osoby nieletnie. Wszelki inny nierząd jest dozwolony [...]”.

Dział VI. Miscellanea to nekrologi oraz - zgodnie z nazwą działu - rozmaite notki i sprawozdania dotyczące na przykład: kongresów naukowych i zjazdów branżowych (adwokatów, aplikantów prawniczych), konkursów na prace na- 
ukowe czy ogłoszeń o nagrodach, honorowych doktoratach i kursach zawodowych. Znajdujemy tu także dyskusje nad projektami aktów prawnych (np. nad projektem prawa małżeńskiego, prawa karnego czy ustawy o spółkach), a również opis planowanej reformy studiów prawniczych.

Interesujące, że w tym dziale zamieszczano także polemiki, zarówno z artykułami, jak i recenzjami. Nierzadko są one dość obszerne (jak na standardy RPEiS) i każdorazowo opatrzone replika autora. Widomy to znak oddziaływania kwartalnika na środowisko, które aktywnie uczestniczy w krytyce naukowej. Budzi to we mnie uczucie zazdrości, bo trudno dopatrzyć się dzisiaj liczniejszych jej przejawów, co owocowałoby na przykład licznymi polemikami w czasopismach.

Moją uwagę w Miscellanea zwrócił dwustronicowy tekst szefa działu ekonomicznego RPEiS: Nauki ekonomiczno-spoteczne w polskich szkotach akademickich. Rysuje on nader mizerny stan tych nauk. Jak podaje autor, kadra profesorska w naukach społeczno-ekonomicznych (bez historii gospodarczej, ale z socjologia, statystyka, organizacją pracy i polityka agrarna) w dwunastu państwowych uczelniach w 1930 r. liczyła 22 osoby (i tyleż katedr), co stanowiło zaledwie 2,8\% ogólnej liczby profesorów w tych uczelniach. Autor ostro krytykuje tradycjonalistyczny model uczelni (pisownia oryginalna):

Zastanawiać np. musi brak katedry ekonomji społecznej w Akademji Górniczej, w Szkole Głównej Gospodarstwa Wiejskiego [...]; zastanawiać musi fakt, że na politechnikach naszych niema bodaj wykładów polityki socjalnej, że na wszystkich uczelniach państwowych w Polsce istnieją tylko dwie katedry statystyki i to jedna z nich obejmuje łącznie skarbowość i statystykę. [...] W stołecznym uniwersytecie na jednego profesora teologji wypadało ostatnio 12 słuchaczów, a wobec 2700 studentów wydziału prawa i przy 4 katedrach ekonomiczno-społecznych (łącznie z socjologja) 675 studentów na jedna katedrę nauk ekonomiczno-społecznych. Warto przytem podkreślić, iż w dobie rozwoju zainteresowania znaczeniem i waga problemów ekonomicznych i socjalnych na 22 katedry ekonomiczno-społeczne w państwowych wyższych uczelniach istnieje 70 katedr filologji i historji literatury, 60 katedr teologji, 122 katedr lekarskich itd.

Konkluzja autora jest pesymistyczna:

Jeśli uzupełnić ten obraz danemi dotyczacemi liczby docentów, których wszystkie uczelnie w zakresie omawianej grupy nauk liczą zaledwie 8-miu, oraz uwaga, że wypadłby on prawdopodobnie jeszcze gorzej, gdyby uwzględnić w obliczeniach wyższe szkoły niepaństwowe (Wyższe Szkoły Handlowe, Wolna Wszechnica, Uniwersytet Lubelski), to trzeba uznać, że istotnie istnieją szczególne powody do niepokoju i troski o ten dział nauk.

No tak, ,istnieją szczególne powody do niepokoju i troski o ten dział nauk”. Lecz czy dzisiaj, gdy studiów (katedr) ekonomiczno-społecznych jest raczej za dużo niż za mało, troski i niepokoje o ten dział nauk przestały nam towarzyszyć? Nie sądzę.

$$
* * *
$$

Fundamentalną różnica, rzucającą się w oczy już po pierwszych stronach, między RPEiS 1932 a większością współczesnych czasopism nauk społecznych jest odbiorca-adresat. W oczywisty sposób RPEiS kilkadziesiąt lat temu adre- 
sowany był do całego środowiska inteligencji społeczno-humanistycznej, zazwyczaj z akademickim cenzusem, w przedwojennej Polsce bardzo przecież nielicznego ${ }^{6}$. Był kwartalnikiem uniwersalnym, ważnym zarówno dla „praktyków”, jak i „teoretyków”. Miał widoczny aspekt akademicki, ale być może jeszcze silniejszy aspekt informacyjno-sprawozdawczy i doradczy (kierowany głównie do prawników i samorządowców). Bez wątpienia RPEiS trafiał do nieporównanie szerszego grona odbiorców niż nasze dzisiejsze kwartalniki. My jesteśmy nastawieni na akademickich specjalistów wąsko zdefiniowanej dyscypliny lub subdyscypliny. Praktycy „nie mają u nas czego szukać”: nie przebiją się przez hermetyczny akademicki język, a nawet gdyby zadali sobie taki trud, to szybko go porzuca. Po co mieliby to robić? Przecież my nader rzadko mamy im coś do powiedzenia; na ogół zresztą w ich problemach słabo się rozeznajemy. Nie oni są naszym docelowym odbiorca, nie ich perspektywa jest nam bliska. Tkwimy w swoich „bańkach”, skupieni na pogoni za grantami i publikacyjnymi punktami.

Istotną różnicą w stosunku do dzisiejszych czasopism jest nie tylko to, co w RPEiS 1932 zostało napisane, ale i to, kto to napisał. Przeważają akademicy, ale zaskakująco dużo jest praktyków, zwłaszcza prawników. Z 18 zamieszczonych w dziale I artykułów, autorami czterech są osoby spoza akademii: „wiceprezes sądu okręgowego”, „adwokat i notarjusz”, „ksiądz-doktor” i „prezes Prokuratorji Generalnej”. Nie przypominam sobie, by autorzy o takim statusie publikowali na przykład w „Studiach Socjologicznych”. Znacznie więcej osób spoza uczelnianego świata znajdujemy w innych działach RPEiS. Autorami recenzji, przeglądów piśmiennictwa, komentarzy i omówień, wyjaśnień prawniczych zawiłości itp., często są „zwykli” inteligenci. Widać gołym okiem silną więź kwartalnika z całym środowiskiem społeczno-humanistycznej inteligencji.

Równie wyraźnie widać nowoczesność kwartalnika i jego otwarcie na świat. Za wskaźnik niech posłuży Przegląd piśmiennictwa. Jak wspomniałem, spis literatury w czterech działach i licznych poddziałach liczy ponad tysiąc obcojęzycznych pozycji. Nie uwzględniam tu 207 recenzji i notek. Większość z nich dotyczy publikacji polskich, lecz aż 73 (35\%) odnosi się do tekstów w językach obcych. Interesujące, jakie są to języki. Otóż w jaskrawym kontraście do dzisiejszej sytuacji, najwięcej omówionych/ zrecenzowanych publikacji jest w języku francuskim (29), następnie niemieckim (23), dopiero na trzecim miejscu angielskim (17), a później włoskim (4). Pokazuje to, że językami ówczesnej inteligencji, w tym świata akademickiego, były przede wszystkim francuski i niemiecki. Pokazuje także, jak swobodnie po światowym (w pierwszym rzędzie europejskim) rynku wydawniczym poruszali się redaktorzy (i zapewne liczni korespondenci) Ruchu. Bez cienia przesady można powiedzieć, że globalizacja, „odkryta” dekady później, była już w wielu aspektach codziennością

${ }^{6}$ Jak szacuje Janusz Żarnowski (1973), ogół pracowników umysłowych w Polsce w 1931 r. to około 716 tysięcy osób, co stanowiło mniej niż 5\% siły roboczej. Przedstawiciele wolnych zawodów zaś - do których w znacznej mierze adresowany był RPEiS - to w 1931 zaledwie około 52 tysięcy osób. 
tego kwartalnika, przynajmniej w tym sensie, że intelektualna i inteligencka Europa (i nie tylko) była w RPEiS silnie reprezentowana. Być może ówczesna Polska była zapóźnionym krajem na peryferiach Europy, lecz z cała pewnościa ani zapóźniony, ani peryferyjny nie był „Ruch Prawniczy, Ekonomiczny i Socjologiczny"; przeciwnie był w centrum Europy, której intelektualny dorobek był doceniany i omawiany, a co najmniej zauważany. Czy możemy to powiedzieć o naszych współczesnych czasopismach?

W kontekście dominacji językowej francuskiego i niemieckiego i odstawania angielszczyzny, prorocze okazały się słowa Floriana Znanieckiego we wspomnianym odczycie Kultura amerykańska. Jedna z głównych tez Znanieckiego jest taka, że Ameryka, dotychczas skupiona na rozwoju materii, wkroczyła „wyraźnie i świadomie na pole twórczości duchowej” i priorytetem na tym duchowym polu uczyniła naukę ${ }^{7}$ I stwierdza: „W powodzi wzbierajacej [amerykańskiej] literatury naukowej dużo jest oczywiście rzeczy mniej wartościowych, lecz z każdym rokiem poziom jej się wznosi, i są już obecnie działy nauki, gdzie lepiej jest znać język angielski, a nie znać żadnego innego, niż znać wszystkie języki, a nie znać angielskiego”. Dzisiaj możemy tylko podziwiać przenikliwość wielkiego polskiego socjologa: zaiste, naukowcom, a już z pewnością socjologom, lepiej jest znać język angielski niż wszystkie inne języki.

$$
* * *
$$

Wskazywałem wyżej na znaczącą różnicę między tym, co 90 lat temu redaktorzy RPEiS kwalifikowali jako „artykuł”, a tym, co my uważamy za „artykuł naukowy”. Bez watpienia wynikało to - tak dzisiaj byśmy to ujęli - z „misji” ówczesnego RPEiS, nakierowanego na znacznie szersze kręgi niż hermetyczny świat akademii, do którego my się odwołujemy. Niemniej refleksja nad istotą akademickiej „produkcji” nie jest w RPEiS 1932 nieobecna. Przykładowo, w recenzji (z. 1/1932) Macieja Starzewskiego (prawnik, prof. UJ) z książki Zbigniewa Makarczyka (będącej pracą doktorską autora) Les oligarchies modernes, wydanej w Lozannie w 1931 r., postawione jest ważne także dzisiaj pytanie, tak przez autora recenzji sformułowane (pisownia oryginalna):

Autor [...] nie ma pretensji do oryginalnych ujęć naukowych. Kroczy wiernie śladami Pareta. Opanował gruntownie doktrynę wielkiego socjologa i zbiera dla niej chętnie potwierdzenia z obserwacyj i sądów innych socjologów tej samej przeważnie szkoły [...]. „Teza” p. Makarczyka świadczy, że zagranicą nie wymaga się od tego rodzaju prac „posuwania nauki naprzód”. Wystarcza, gdy kandydat opanował literaturę, - wykazał, że umie posługiwać się metodą naukowa, potrafi postawić jasno problem i rozwiązać go zgodnie z przyjętemi założeniami, gdy inteligentnie rozwija i uzupełnia idee mistrzów, pracę przytem buduje jasno, logicznie, ekonomicznie, przedstawiając swe wywody zajmująco i z talentem.

${ }^{7} \mathrm{~W}$ nawiązaniu do wspomnianej mizerii nauk społeczno-ekonomicznych na polskich uczelniach, Znaniecki pokazuje dystans, jaki wówczas dzielił instytucjonalizację socjologii amerykańskiej od europejskiej: „Przytoczę tylko jeden przykład najlepiej mi znany - przykład socjologji. Ta nauka, względnie nowa [...] ma dziś katedry w stu kilkudziesięciu [amerykańskich] uniwersytetach [...], a tylko trzy z tych uniwersytetów, w Chicago, Los Angeles i New Yorku mają więcej katedr niż cała Europa”. 
„Nie ma pretensji do oryginalnych ujęć naukowych”: czyż to nie nader elegancki sposób wyrażenia rozczarowania, że doktorat ma li tylko sprawozdawczo-deskryptywny charakter? Mocniej recenzent stawia ten problem kilka zdań później: „zagranicą nie wymaga się od tego rodzaju prac "posuwania nauki naprzód». No właśnie: czy kryterium przyjęcia doktoratu, a w naszym kontekście akceptacji do druku artykułu, należy uczynić „posuwanie nauki naprzód"? Przez wielu jest ono rozumiane jako testowanie hipotez, podważanie dotychczasowej wiedzy, odkrywanie nieodkrytego; najogólniej i upraszczająco ujmując, jest utożsamiane z (neo)pozytywistycznym modelem nauki. Czy artykuł do kwartalnika naukowego o takich (i tylko takich!) walorach, jakie Starzewski przypisał doktoratowi Makarczyka w końcowym fragmencie recenzji, zasługuje na publikację? Czy, inaczej mówiąc, mamy przyjąc wzór obowiąujący w naukach przyrodniczych i uczynić go kryterium „naukowości” (lub „akademickości”) naszych czasopism?

Rozważaliśmy takie pytania kilka lat temu w „Studiach Socjologicznych”. Początkowo zdania były podzielone, ale w toku dyskusji zdecydowanie przeważył pogląd, że artykuły zbudowane wedle modelu nauk przyrodniczych sa wprawdzie mile widziane, lecz w żadnym razie nie może to oznaczać odrzucania innych tekstów. Tym bardziej że artykuły (eseje) syntetyzujące, przeglądowe i systematyzujace daną problematykę cieszą się dużym zainteresowaniem czytelników. Świadczy o tym choćby mający taki właśnie charakter rocznik „Annual Review of Sociology”, znajdujący się od lat w ścisłej czołówce rankingu cytowań ${ }^{8}$.

Gdy czyta się fragmenty dwunastego rocznika RPEiS, uderzającą różnica w stosunku do współczesnych czasopism jest język. Dałem temu wyraz, podkreślając fragmenty przytoczonej recenzji. W dalszej jej części prof. Starzewski bezpośrednio zwraca uwagę na walory językowe książki:

\begin{abstract}
Podnieść także należy dobry styl autora, poważny, zwarty, wolny od tej płynności i niby swady, co wytartemi kliszami, pustą frazeologja, staroświeckiemi elegancjami obrzydza niestety tak często czytanie francuskich prac doktorskich naszych rodaków. Wszystko to czyni, że można powitać w autorze nową siłę, która opanowawszy już narzędzia, zacznie w przyszłości wzbogacać naprawdę naukę [...].
\end{abstract}

Surowy recenzent nie może darować Makarczykowi odtwórczego charakteru dzieła (,zacznie w przyszłości wzbogacać naprawdę naukę”), lecz chwali jego stylistykę, przeciwstawiając ją tekstom operującymi „wytartemi kliszami” i „pustą frazeologią”. Niestety, to językowe spsienie rozlało się gigantycznie i jest mi dobrze znane z lektury dziesiątek prac magisterskich, doktorskich, habilitacyjnych, a także - choć w mniejszym stopniu - z tekstów nadsyłanych do „Studiów Socjologicznych”. Na porządku dziennym jest język powielający schematy, sztampowy, naładowany niekończącymi się kalkami z angielszczyzny, pseudoprecyzyjny, zawierający dokładnie to wszystko, co 90 lat temu

${ }^{8}$ Misja kilkudziesięciu czasopism wydawanych pod wspólnym tytułem „Annual Review of...” głosi, że sa one „dedicated to synthesizing and integrating knowledge for the progress of science and the benefit of society”. „Annual Review of Sociology” w ranking Journal Citation Report 2020 zajmuje pierwsze miejsce wśród 150 analizowanych czasopism socjologicznych. 
recenzent określał jako wytarte klisze i pustą frazeologię. Wykwintna polszczyzna jako język komunikacji (akademickiej) inteligencji jest w odwrocie. Kto dziś napisze taką recenzję, jaką Czesław Znamierowski (4/1932) opatrzył książkę Antoniego Słonimskiego Moja podróż do Rosji? Taki jest jej początek:

\begin{abstract}
Nie zaopatrzona żadnym stemplem naukowym, nie subsydjowana z żadnego funduszu, poprostu w serji beletrystycznej znanego wydawnictwa, ukazała się niewielka książka o Rosji, napisana przez znanego poetę. Nie masz w niej napuszonych, wymyślnych a niepomysłowych słów, któreby udawały precyzyjną terminologję naukowa. Tylko bezpretensjonalny opis rzeczy widzianych i przeżytych. Ważę się przecież powiedzieć, że książka ta daje więcej wiedzy głębokiej o rzeczach ludzkich i o niezmiennych prawach ludzkiego współżycia, niż niejeden majestatycznie rozstroniczony traktat socjologiczny. [Pisownia oryginalna].
\end{abstract}

I dalej oceniajac książkę Słonimskiego, Znamierowki odwołuje się do takich na przykład charakterystyk autora i jego dzieła: „ograniczył się do własnej autopsji, czujnej, nieufnej i chytrej”; „szukał rzeczywistości, niesfałszowanej reklama, propagandą i aktorstwem”; „z maestrją humorysty opowiada o ekscesach religji materjalistycznego pojmowania dziejów”; „z odraza patrzy na opasłą bestję krasnoarmiejską”; „i piękno, które jest zawsze w prostem i jasnem słowie, kumulującem wielką siłę uczucia”; „gratuluję autorowi nadlordowskiej prawdomówności”. Nie jestem wprawdzie pewien, czy dobrze domyślam się, co autor miał na myśli, pisząc o „majestatycznie rozstroniczonym traktacie socjologicznym”, i nie wiem, co znaczy „ponadlordowska prawdomówność" (bardziej prawdomówny niż lord?), lecz bez wątpienia recenzje napisane tak pięknym i barwnym językiem każdy redaktor chciałby dostawać jak najczęściej. Szkoda, że rzadko mamy dzisiaj okazje napotkać podobne teksty w naszych kwartalnikach.

$$
* * *
$$

Z nakreślonych uwag, mam nadzieję, jasno wynika, że podoba mi się profil przedwojennego „Ruchu Prawniczego, Ekonomicznego i Socjologicznego”. Powiem więcej: tęsknię za takim kwartalnikiem. Nieśmiało zaczęła mi chodzić po głowie myśl, że może warto powołać do życia czasopismo o zbliżonym profilu. Zapewne powiecie, że taki model nie ma dzisiaj racji bytu. W Internecie, jak wiadomo, ,jest wszystko”, w tym niekończące się strony informacyjne i sprawozdawcze relacjonujace zagadnienia społeczne, fora dyskusyjne, nie mówiąc o setkach mniej czy bardziej efemerycznych biuletynów, jednodniówek i periodyków o rozmaitej proweniencji teoretycznej, ideologicznej czy politycznej. Każdy znajdzie coś dla siebie. Po co więc taki staroświecki periodyk? Ja odpowiem: właśnie po to, by powstał ośrodek skupienia, przekraczający waskie granice dyscyplin i selekcjonujący powódź informacji zalewających nas Internetową mierzwa. By poprzez napisane literacka polszczyzna teksty, zrozumiałe dla prawnika, ekonomisty, antropologa społecznego, socjologa, politologa, także literaturoznawcy, historyka, badacza kultury i mediów, integrować środowisko akademickiej inteligencji humanistyki i nauk społecznych. By stworzyć forum dla cywilizowanych dyskusji i sporów wykraczających poza waskie ramy naszych dyscyplin, wiernie odwzorowane w tysiącach obecnych 
akademickich periodyków. By zmusić nas do wychodzenia z wyspecjalizowanych „baniek”, w jakich tkwimy, nie widząc i nie rozumiejąc zewnętrznego świata. By przyciagać światłą inteligencję pozaakademicka, w tym praktyków życia społecznego. I nie zastapi tego Internet - to cudowne narzędzie, którym zachłysnęliśmy się dwie dekady temu - który ujawnił swoje drugie oblicze. Przeistoczył się w znacznej mierze w rynsztok, w ściek, którym spływają brudy globalnego świata. Oczywiście nie należy wylewać dziecka razem z kapiela i w żadnym razie nie sugeruję, że z dobrodziejstw sieciowej rzeczywistości mielibyśmy rezygnować. Niemniej może nadeszła pora, byśmy poważnie pomyśleli o powrocie do tych aspektów przeszłości, które - paradoksalnie - w diametralnie zmienionym kontekście ujawniają swoje ponadczasowe walory.

Hintz, M., Nęcka, E., Prostak, R., Welfe, A. (2019). Jak powstał nowy wykaz czasopism naukowych. Forum Akademickie 11.

Kulikowski, K., Antipow, E. (2020). Niezamierzone konsekwencje punktozy jako wartości kulturowej polskiej społeczności akademickiej. Studia Socjologiczne 3(238): 207-236.

Słomczyński, K.M. (2020). Co to są 'nauki socjologiczne' w polskiej klasyfikacji dziedzin i dyscyplin naukowych. Studia Socjologiczne 3(238): 187-205.

Wincławski, W. (2011). „Studia Socjologiczne”. Okoliczności powstania i status czasopisma w socjologii polskiej. Studia Socjologiczne 1(200): 11-38.

Żarnowski, J. (1973). Społeczeństwo Drugiej Rzeczypospolitej. Warszawa: PWN.

\section{SOCIAL SCIENCE JOURNALS: REFLECTIONS ON THE CENTENARY OF RUCH PRAWNICZY, EKONOMICZNY I SOCIOLOGICZNY}

\section{Summary}

The centenary anniversary of Ruch Prawniczy, Ekonomiczny $i$ Socjologiczny is a good time for reflection on the status of social science journals in Poland. The article compares the form and content of the twelfth volume (1932) of RPEiS with today's academic journals. The major conclusion is that the pre-WWII journal was targeted at the broadly defined milieu of the humanistic intelligentsia, while today's journals are addressed exclusively to a narrow group of academic specialists. Is there a chance of establishing a social science periodical in Poland that would attract a broader readership, including both scientists and practitioners in the field of the social sciences?

Keywords: old and new social science journals: the form and content of journals, authors and language 
